\title{
REINFORCEMENT CREATIVE THINKING ABILITIES OF MADRASAH ALIYAH STUDENTS THROUGH GUIDED DISCOVERY COMBINED WITH BRAINSTORMING IN BIOLOGY
}

\author{
Muhamad Wajid Wardana ${ }^{1}$, Riezky Maya Probosari ${ }^{2}$, Murni Ramli $^{3}$, Suwarti $^{4}$ \\ Universitas Sebelas Maret ${ }^{1,2,3}$, MAN 2 Kebumen $^{4}$
}

\section{Sejarah Artikel}

Diterima 20 Oktober 2018

Disetujui 26 Desember 2018

Diterbitkan 31 Desember 2018

\section{Kata Kunci}

Guided Discovery,

Brainstorming, Creative

Thinking Ability

\begin{abstract}
Abstrak
This research aims to reinforce students' creative thinking ability in MAN 2 Kebumen by applying guided discovery learning combined with brainstorming. This study is a Classroom Action Research has been done in three cycles. Each cycle consisted of planning, action, observation, and reflection follow the spiral method of Kemmis \& Taggart. The subjects were 32 students of grade tenth MIA 1 of MAN 2 Kebumen academic in year 2017/2018. The data research obtained through observation, interviews, and test. Data was analysis by qualitative descriptive techniques. Data validation use triangulation techniques. The results shows that implementation of guided discovery learning combined with brainstorming can reinforce students' creative thinking ability. Reinforce of the thinking ability of students can be seen through cognitive test result. The result shown that average students' creative thinking ability score at pre-cycle was $31,64 \%$, the first cicle was $37,30 \%$, the second cycle was $46,87 \%$, and the third cycle was $48,43 \%$. Conclusion of this research is guided discovery learning combined with brainstorming were able to reinforce creative thinking ability students grade tenth MIA 1 of MAN 2 Kebumen.

\section{Cara Mengutip}

Muhamad Wajid Wardana, M.W., Probosari, R.M., Ramli, M., Suwarti. (2018). Reinforcement Creative Thinking Abilities of Madrasah Aliyah Students Through Guided Discovery Combined With Brainstorming in Biology. DWIJA CENDEKIA Jurnal Riset Pedagogik, 2 (2), 55-63
\end{abstract}

Korespondensi Penulis: 


\section{PENDAHULUAN}

Berpikir merupakan hal yang tidak dapat terpisahkan dari kehidupan manusia. Semua orang pasti berpikir dan menghasilkan apa yang orang mau bergantung pada kemampuan pemikiran mereka (Soheila Shafiee Varzaneh \& Roya Baharlooie, 2015). Pengembangan kemampuan berpikir sebagai potensi peserta didik didalam pendidikan perlu diberdayakan. Salah satu kemampuan berpikir yang dapat diberdayakan sesuai abad ke-21 ini adalah kemampuan berpikir kreatif (Ritter \& Mostert, 2016).

Biologi merupakan salah satu mata pelajaran yang memiliki arah untuk membekali peserta didik menghadapi tantangan di abad ke-21. Arah yang dimaksudkan adalah pengalaman belajar. Pengalaman belajar perlu dilatihkan sehingga membekali peserta didik menjadi pribadi yang memiliki kemampuan kolaboratif, komunikatif, dan kreatif. Hal tersebut sesuai dengan UndangUndang Sistem Pendidikan Nasional (Sisdiknas) nomor 20 tahun 2003 pasal 3 menyebutkan bahwa pendidikan nasional berfungsi mengembangkan potensi peserta didik agar menjadi manusia yang beriman dan bertakwa kepada Tuhan Yang Maha Esa, berakhlak mulia, sehat, berilmu, cakap, kreatif, mandiri, dan menjadi warga negara yang demokratis serta bertanggungjawab.

Kemampuan berpikir kreatif merupakan hasil interaksi antara individu dan lingkungannya. Seseorang dipengaruhi dan mempengaruhi oleh lingkungan dimana ia berada, dengan demikian baik perubahan didalam individu maupun didalam lingkungan dapat menunjang kemampuan berpikir kreatif. Pada kenyataannya, dalam proses pembelajaran selama ini, lebih menekankan hafalan dan mencari satu jawaban yang benar untuk soalsoal yang diberikan, proses berpikir tingkat tinggi termasuk kemampuan berpikir kreatif jarang dilatihkan (Rahmi dkk, 2016).

Hasil pengamatan awal di kelas X MIA 1 Madrasah Aliyah Negeri 2 Kebumen, guru hanya menggunakan metode ceramah. Observasi atau pengamatan awal dilaksanakan sebanyak tiga kali. Hasil pengamatan awal yang didapatkan pada pertemuan pertama adalah (1) metode yang digunakan oleh guru selama proses pembelajaran adalah ceramah satu arah, (2) peserta didik jarang diberi kesempatan untuk berpendapat, dan (3) tidak ada feedback dari peserta didik untuk bertanya. Pada pertemuan kedua adalah (1) metode yang digunakan guru masih berupa ceramah, (2) ketika guru memberikan umpan berupa pertanyaan sebagian besar peserta didik menjawab secara bersama-sama, apabila peserta didik ditunjuk langsung untuk mengajukan pendapat, maka peserta didik tersebut kurang lancar dalam mengemukakan pendapat, (3) pendapat yang diberikan oleh peserta didik singkat dan kurang mendetail. Pada pertemuan ketiga adalah (1) metode yang digunakan oleh guru masih menggunakan ceramah, (2) ketika guru memberikan permasalahan untuk dicari solusinya, hanya ada 2 peserta didik yang mengajukan pendapat dan solusi, (3) solusi yang diberikan peserta didik ketika diberi pertanyaan oleh guru hanya bersumber dari buku teks. 
Pada saat observasi lanjutan, dilakukan tes terhadap kemampuan berpikir kreatif peserta didik. Berdasarkan hasil tes kemampuan berpikir kreatif awal peserta didik, aspek fluency berada pada persentase 36,71 \%. Aspek flexibility sebesar $32,03 \%$, aspek elaboration sebesar $32,81 \%$, dan aspek originality sebesar 25\%. Rata-rata kemampuan berpikir kreatif peserta didik di kelas $X$ MIA 1 Madrasah Aliyah Negeri 2 Kebumen hanya sebesar 31,64\%. Menurut (Herlina, 2017), persentase yang didapatkan pada rentang $0-20$ $\%$ berada pada kategori kemampuan berpikir kreatif yang sangat rendah. Persentase yang didapatkan pada rentang 21 - $40 \%$ berada pada kategori kemampuan berpikir kreatif rendah. Persentase yang didapatkan pada rentang 41 - $60 \%$ berada pada kategori kemampuan berpikir kreatif yang cukup. Persentase yang didapatkan pada rentang 61 - $80 \%$ berada pada kategori kemampuan berpikir kreatif yang tinggi, serta persentase yang didapatkan pada rentang 81 - $100 \%$ berada pada kategori kemampuan berpikir kreatif yang sangat tinggi. Hasil tes observasi lanjutan tersebut jika diukur rentang persentase dari (Herlina, 2017) menunjukkan bahwa kemampuan berpikir kreatif peserta didik berada pada kategori rendah dan memang perlu penguatan untuk meningkatkan kemampuan berpikir kreatif.

Fakta observasi yang dilakukan peneliti dan tujuan pembelajaran biologi yang sesungguhnya, perlu dicari model pembelajaran yang tepat. Model pembelajaran yang tepat akan berdampak pada peningkatan kemampuan berpikir kreatif mereka. Model pembelajaran tersebut menciptakan lingkungan belajar terutama melibatkan pengalaman nyata peserta didik dalam pembelajaran. Salah satu model yang dapat diterapkan adalah discovery learning. Bruner merupakan landasan dari perwujudan model discovery learning. (Joolingen, 1999) mengemukakan bahwa discovery learning merupakan sebuah pembelajaran dimana peserta didik membangun pengetahuannya sendiri dengan meneliti dan bereksperimen. Melalui kegiatan tersebut, peserta didik dapat lebih memahami pengetahuan secara kontekstual dan bermakna, dibandingkan dengan hanya menerima transfere knowledge dari guru. Bruner dalam (Widodo, 2010) mengungkapkan bahwa discovery learning sesuai dengan pencarian pengetahuan secara aktif oleh manusia dan dengan sendirinya memberikan hasil yang paling baik, berusaha sendiri untuk mencari pemecahan masalah serta pengetahuan yang menyertainya, dan menghasilkan pengetahuan yang benar-benar bermakna.

Menurut (Sapriati \& Amalia, 2009), ada dua macam atau jenis discovery learning, yaitu : (1) model penemuan murni (free discovery learning) dan (2) model penemuan terarah atau penemuan terbimbing (guided discovery learning). Model murni merupakan model pembelajaran penemuan tanpa adanya petunjuk atau arahan. Sedangkan model penemuan terarah/terbimbing (guided discovery learning) merupakan model pembelajaran yang membutuhkan peran guru sebagai fasilitator dalam proses pembelajarannya. Pembelajaran penemuan terbimbing (guided discovery learning) lebih banyak diterapkan dibandingkan pembelajaran penemuan murni, karena dalam pembelajaran penemuan terbimbing guru akan 
memberikan petunjuk kepada peserta didik sehingga peserta didik akan lebih terarah dalam rangka mencapai tujuan yang telah ditetapkan. Oleh karena itu, dalam penelitian ini digunakan model guided discovery learning.

Untuk merangsang kemampuan berpikir peserta didik, dibutuhkan sesi merangsang kemampuan berpikir. Salah satu caranya adalah dengan menggunakan brainstorming. Menurut (Roestiyah, 2008), brainstorming yaitu teknik mengajar yang dilakukan guru dengan cara melontarkan suatu masalah ke kelas oleh guru, kemudian peserta didik menjawab, menyatakan pendapat, atau memberi komentar sehingga memungkinkan masalah tersebut berkembang menjadi masalah baru. Sedangkan menurut Rawlinson (2004) dalam (ChoonKeong, Harun, Aris, \& Kean-Wah,
2012), brainstorming adalah cara untuk mendapatkan banyak ide dari sekelompok manusia dengan cara yang singkat.

Dari 2 pendapat diatas,
brainstorming adalah salah satu
metode yang dapat merangsang
$\begin{aligned} & \text { kreativitas. } \\ & \text { mengkombinasikan }\end{aligned}$ Brainstorming
pendekatan
informal dalam pemecahan masalah dengan berpikir lateral. Hal ini mendorong peserta didik untuk berpikir dan mencetuskan ide-ide. Beberapa ide-ide tersebut dapat menjadi ide yang original (asli), solusi kreatif dari pemecahan masalah, atau memicu ide-ide lain yang lebih banyak. Dengan karakteristik model guided discovery learning dan paduan dari brainstorming diharapkan kemampuan berpikir kreatif. peserta didik dapat diperbaiki dan menguat.

\section{METODE PENELITIAN}

Jenis penelitian yang digunakan adalah penelitian Tindakan Kelas (PTK) dilaksanakan selama bulan April-Mei 2017. Tindakan ditekankan pada pelaksanaan guided discovery dipadu brainstorming untuk meningkatkan kemampuan berpikir kreatif pada materi pencemaran lingkungan. Subjek penelitian adalah siswa kelas X MIA 1 disalah satu MA Negeri di Kebumen yang berjumlah 32 orang. Data penelitian diperoleh melalui observasi, wawancara, dokumentasi, dan tes. Data utama kemampuan berpikir kreatif bersumber dari data hasil tes. Pengukuran kemampuan berpikir kreatif adalah dengan memberikan soal essay dengan jumlah 4 butir soal. Dalam penilaiannya, setiap jawaban tertinggi akan mendapatkan 4 skor dan jawaban paling rendah akan mendapatkan 1 skor berdasarkan rubrik penilaian tes kemampuan berpikir kreatif yang diadaptasi dan dikembangkan oleh Treffinger, 2002. Teknik uji validitas data menggunakan teknik triangulasi (Sugiyono, 2013). Teknik analisis data menggunakan teknik analisis deskriptif. (Miles dan Hubberman, 1984). Prosedur penelitian menggunakan Kemmis dan Mc. Taggart (1988) dalam (Arikunto, Suhardjono \& Supardi, 2008, yang meliputi tahap perencanaan, tindakan dan observasi, dan refleksi. Target yang diharapkan adalah adanya peningkatan kemampuan berpikir kreatif, dengan presentase capaian peningkatan yang ditargetkan adalah $15 \%$ dari baseline. 


\section{PEMBAHASAN}

Hasil yang didapatkan terhadap pratindakan, siklus 1, siklus 2, dan penilaian kemampuan berpikir kreatif siklus 3 terdapat pada tabel 1 .

Tabel 1. Skor kemampuan berpikir kreatif pada pratindakan, siklus 1, 2, dan 3

\begin{tabular}{llccccc}
\hline No & \multirow{2}{*}{ Aspek } & $\begin{array}{c}\text { Pra } \\
\text { tindakan }\end{array}$ & $\begin{array}{c}\text { Siklus } \\
\text { I }\end{array}$ & $\begin{array}{c}\text { Siklus } \\
\text { II }\end{array}$ & $\begin{array}{c}\text { Siklus } \\
\text { III }\end{array}$ & $\begin{array}{c}\text { Peningkatan } \\
\text { (skor) }\end{array}$ \\
\hline 1 & Fluency & 47 & 53 & 70 & 73 & 16 \\
2 & Flexibility & 41 & 52 & 61 & 62 & 21 \\
3 & Elaboration & 42 & 50 & 65 & 61 & 19 \\
4 & Originality & 32 & 36 & 44 & 52 & 20 \\
\hline
\end{tabular}

Berdasarkan tabel 1 diatas, kemampuan berpikir kreatif yang peningkatan kemampuan berpikir diperoleh masing-masing peserta kreatif yang tertinggi ada pada aspek didik. Kemampuan berpikir kreatif flexibility yaitu sebesar 21 poin, peserta didik pada siklus 1, 2, dan 3 kemudian aspek originality sebesar 20 secara umum mengalami peningkatan poin, disusul aspek elaboration dibanding pratindakan. Perbandingan sebesar 19 poin, dan terakhir aspek kemampuan berpikir kreatif masingfluency sebesar 16 poin.

Kemampuan berpikir kreatif peserta didik dianalisis lebih dalam berdasarkan perolehan skor tes masing peserta didik pada pratindakan, siklus 1 , siklus 2 , dan siklus 3 seperti gambar 1 .

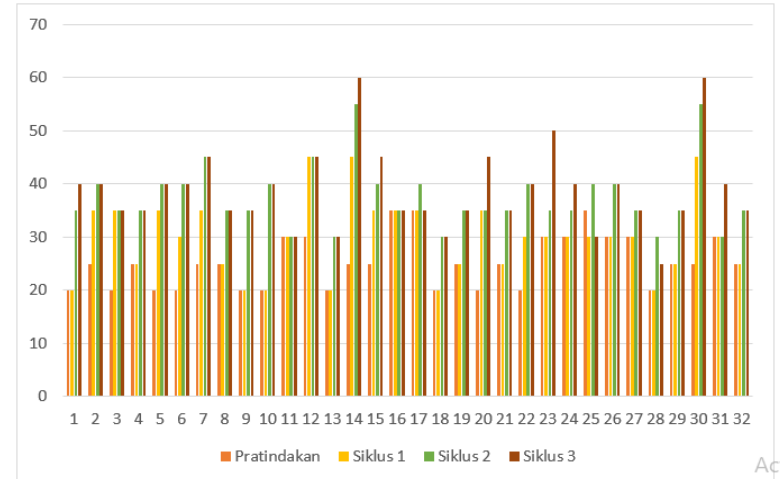

Gambar 1. Perbandingan kemampuan berpikir kreatif peserta didik pada pratindakan, siklus 1 , siklus 2 , dan siklus 3

$\begin{array}{lrrr}\text { Capaian } & \text { rata-rata kelas } & \text { juga } & \text { Peningkatan tersebut ditunjukkan oleh } \\ \text { mengalami } & \text { peningkatan } & \text { dari } & \text { gambar } 2 . \\ \text { pratindakan } & \text { sampai siklus } & 3 . & \end{array}$




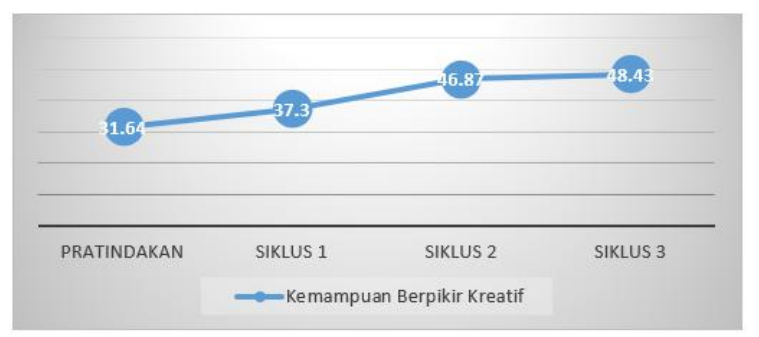

\section{Gambar 2. Persentase Rata-Rata Kemampuan Berpikir Kreatif Berdasarkan Tes Pada Pratindakan, Siklus 1, Siklus 2, dan Siklus 3}

Berdasarkan gambar 2 , diperoleh data bahwa capaian ratarata kelas untuk kemampuan berpikir kreatif pada setiap tindakan mengalami peningkatan. Pada pratindakan, capaian rata-rata kelas berada pada 31,64\%. Meningkat pada siklus 1 sebesar $5,66 \%$, menjadi $37,30 \%$. Meningkat lagi pada siklus 2 sebesar $9,57 \%$, menjadi $46,87 \%$, dan pada siklus 3 meningkat lagi sebesar $1,56 \%$ menjadi $48,43 \%$.

Pembahasan

Penggunaan model guided discovery learning dipadu brainstorming pada penelitian ini telah mampu memperbaiki kemampuan berpikir kreatif peserta didik Madrasah Aliyah Negeri 2 Kebumen. Hal tersebut ditunjukkan oleh hasil yang didapatkan saat pelaksanaan tindakan mulai dari siklus 1 sampai dengan siklus 3. Hasil yang didapatkan saat pratindakan sebesar $31,64 \%$, berubah menjadi $48,43 \%$ pada siklus 3 . Hal tersebut menandakan bahwa rata-rata capaian kelas untuk kemampuan berpikir kreatif meningkat sebesar $16,79 \%$.

Kemampuan berpikir kreatif merupakan kemampuan yang meliputi kemampuan fluency (berpikir lancar), kemampuan flexibility (berpikir luwes), dan kemampuan originality (berpikir orisinal). Peserta didik memenuhi tingkat kemampuan berpikir kreatif yang baik apabila (1) mampu mengungkapkan banyak gagasan dengan lancar dalam proses pemecahan masalah (aspek fluency), (2) keluwesan peserta didik dalam menginterpretasikan permasalahan kedalam bentuk gambar atau cerita dan menggolongkan hal-hal berdasarkan kategori tertentu (aspek flexibility), serta (3) keaslian dalam menemukan solusi permasalahan baru, yang merupakan hasil pemikiran sendiri (aspek originality) (Rababah, et.al, 2013).

Model pembelajaran guided discovery learning menurut Veermans, (2003) terdiri atas tahap orientation, tahap hypothesis generation, tahap hypothesis testing, tahap conclusion, dan tahap regulation process : evaluation. Tahap orientation adalah tahapan yang mengakomodasi peserta didik membangun ide tentang pembelajaran dengan informasi awal yang telah ada berdasarkan fenomena yang dihadirkan.

Tahap hypothesis generation adalah tahapan yang memfasilitasi peserta didik untuk menyusun hipotesis atau pertanyaan. Tahap hypothesis testing adalah kegiatan merancang dan melaksanakan proses pembelajaran untuk menemukan pengetahuan. Tahap conclusion adalah tahapan yang mengakomodasi peserta didik untuk menyusun kesimpulan berdasarkan hasil kegiatan yang dilakukan selama proses pembelajaran. Tahap 
regulation process : evaluation adalah tahapan yang terdiri dari kegiatan refleksi dan evaluasi. Refleksi merupakan tahapan untuk mengkonfirmasi hasil kegiatan selama proses pembelajaran, sedangkan evaluasi merupakan kegiatan untuk mengukur ketercapaian tujuan pembelajaran.

Setiap tahapan dalam model pembelajaran guided discovery learning meningkatkan kemampuan berpikir kreatif peserta didik. Hal tersebut sesuai dengan capaian ratarata kelas untuk kemampuan berpikir kreatif pada setiap tindakan mengalami peningkatan. Pada pratindakan, capaian rata-rata kelas berada pada 31,64\%. Meningkat pada siklus 1 sebesar $5,66 \%$, menjadi $37,30 \%$. Meningkat lagi pada siklus 2 sebesar $9,57 \%$, menjadi $46,87 \%$, dan pada siklus 3 meningkat lagi sebesar $1,56 \%$ menjadi $48,43 \%$.

\section{SIMPULAN}

Berdasarkan hasil penelitian dapat disimpulkan bahwa penerapan model pembelajaran guided discovery learning dipadu brainstorming mampu memperbaiki kemampuan berpikir kreatif siswa dalam pembelajaran biologi kelas X MIA 1 MAN Kebumen 2 tahun pelajaran 2016/2017.

\section{DAFTAR PUSTAKA}

Ahmadi. (2012). Identifikasi Tingkat Berpikir Kreatif Siswa dalam Memecahkan Masalah Materi Persamaan Garis Lurus ditinjau dari Kemampuan Matematika Siswa dan Perbedaan Jenis Kelamin. [Skripsi tidak dipublikasikan]. Universitas Negeri Surabaya. Surabaya.

AlMutairi, A. N. (2015). The Effect of Using Brainstorming Strategy in Developing Creative Problem Solving Skills among male Students in Kuwait : A Field Study on Saud Al-Kharji School in Kuwait City. Journal of Education and Practice, Vol.6, No.3, Hal : 136-146.

Baer, J. (2017). Content Matters: Why Nurturing Creativity Is So Different in Different Domains. Creativity Theory and Action in Education, Hal : 129-140.

Bono, E. D. (2007). Revolusi Berpikir : "Belajar Berpikir Canggih dan
Kreatif dalam Memecahkan Masalah dan Meantik Ide-lde Baru. Terjemahan Ida Sitompul dan Fahmy Yamani (Buku Asli Diterbitkan Tahun 1993). Bandung : Kaifa.

Choon-Keong, T., Harun, J., Aris, B., \& Kean-Wah, L. (2012). ENHANCING AND ASSESSING STUDENT TEACHERS' CREATIVITY USING BRAINSTORMING ACTIVITIES AND ICT-BASED MORPHOLOGICAL ANALYSIS METHOD. Academic Research International, 241-250.

Daryanto. (2009). Panduan Proses Pembelajaran Kreatif \& Inovatif. Jakarta: Publisher.

Filsaime,D.K. (2008). Menguak Rahasia Berpikir Kritis dan Kreatif. Jakarta: Prestasi Pustaka.

Hargrove, R. A. (2013). Assessing the long-term Impact of a 
Metacognitive Approach to Creative Skill Development. Int J Technol Des Educ, Hal : 489517.

Herlina, L. (2017). Analisis Kemampuan Berpikir Kreatif Siswa Pada Materi Virus Kelas $\mathrm{X}$ Mas Al-Mustaqim Sungai Raya 2. Jurnal Bioeducation, Vol. 2, No. 1, Agustus 2017.

Huberman, M. \&. (1984). Analisis Data Kualitatif : Buku Sumber Tentang Metode-metode Baru. . Jakarta: Universitas Indonesia Press.

Joolingen, W. V. (1999). Cognitive Tools for Discovery Learning. International Journal of Artificial Intelligence in Education, Vol : 10, 385-397.

Kampylis, P., \& Berki, E. (2014). Nurturing Creative Thinking. In S. VOSNIADOU, Educational Practices Series (pp. 1-28). Switzerland: International Bureau of Education.

Kemmis , S., \& McTaggart, R. (2007, 01 01). PARTICIPATORY ACTION RESEARCH.

Retrieved from

http://citeseerx.ist.psu.edu: http://citeseerx.ist.psu.edu/view doc/download?doi=10.1.1.473. 4759\&rep=rep1\&type $=$ pdf

Markaban. 2008. Model Penemuan Terbimbing pada Pembelajaran Matematika SMK. Yogyakarta : Pusat pengembangan dan pemberdayaan pendidik dan tenaga kependidikan.

Munandar, Utami. 2002. Kreativitas dan Keberbakatan Strategi Mewujudkan Potensi Kreatif dan Bakat. Jakarta : Gramedia Pustaka Utama.

Munandar, Utami. Pengembangan Kreatifitas
Anak Berbakat. Jakarta : Rineka Cipta

Nupita, E. (2013). PENERAPAN MODEL PEMBELAJARAN PENEMUAN TERBIMBING UNTUK MENINGKATKAN HASIL BELAJAR DAN KETERAMPILAN PEMECAHAN MASALAH IPA PADA SISWA KELAS $V$ SEKOLAH DASAR. JPGSD, Volume 01 Nomor $02 \mathrm{Hal}: 1-9$.

Oncu, , E. C. (2016). Improved creative thinkers in a class: A model of activity based tasks for improving university students' creative thinking abilities. Educational Research and Reviews, 11(8), 517-522.

Rahmawati, S. 2001. Mencetak Anak Cerdas dan Kreatif. Jakarta, PT. Kompas Media Nusantara.

Rahmi, D., Rusman, \& Erlidawati. (2016). Identifikasi Kemampuan Berpikir Kreatif Siswa Kelas XI Menggunakan Soal Tes OpenEnded Problem Pada Materi Koloid Di SMA/MA Kota Banda Aceh. Jurnal Ilmiah Mahasiswa Pendidikan Kimia, 60-69.

Ritter, S. M., \& Mostert, N. (2016). Enhancement of Creative Thinking Skills Using a Cognitive-Based Creativity Training. Springerlink.com, 111.

Roestiyah. (2008). Strategi Belajar Mengajar. Jakarta: Rineka Cipta.

Sapriati, \& Amalia. (2009). Materi Pokok Pembelajaran IPA. Jakarta: Universitas Terbuka.

Siswono, T. Y. (2011). Pembelajaran Matematika Berbasis Pengajuan dan Pemecahan Masalah (JUCAMA) untuk Meningkatkan Kemampuan Berpikir Kreatif Siswa. 
Prosiding Seminar Nasional Matematika (pp. Hal : 14-32). Surabaya: Universitas Negeri Surabaya.

Soheila Shafiee Varzaneh \& Roya Baharlooie. (2015). The Effect of Virtual vs. Traditional Classroom Instruction on Creative. English Language Teaching, 177-188.

Solso, Robert L. 2007. Psikologi Kognitif. Jakarta : Erlangga.

Sugiyono. (2013). Metode Penelitian Pendidikan. Bandung: Alfabeta.

Sumarmo, Utari. 2010. Berpikir dan Disposisi Matematik: Apa, Mengapa, dan Bagaimana Dikembangkan pada Peserta Didik. Artikel pada FPMIPA UPI Bandung.

Susilo, H., Chotimah , H., \& Sari, D. Y. (2008). Penelitian Tindakan

\section{Kelas Sebagai Sarana \\ Pengembangan \\ Keprofesionalan Guru dan \\ Calon Guru. Malang:}

Bayumedia.

Tampubolon, S. (2014). Penelitian Tindakan Kelas Sebagai Pengembangan Profesi Pendidik dan Keilmuan. Jakarta: Penerbit Erlangga.

Treffinger, D. J., Young, G. C., Selby, E. C., \& Shepardson, C. (2002). Assessing Creativity : A Guide for Educators. Sarasota, Florida: Center for Creative Learning.

Veermans, K. (2003). Intelligent support for discovery learning. Netherlands: Twente University Press.

Widodo, A. (2010). Pendidikan IPA di Sekolah. Bandung: UPI Press. 